\title{
Biochar can be used to capture essential nutrients from dairy wastewater and improve soil physico-chemical properties
}

\author{
T. A. Ghezzehei, D. V. Sarkhot, and A. A. Berhe \\ School of Natural Sciences, University of California, Merced, CA 95343, USA \\ Correspondence to: T. A. Ghezzehei (taghezzehei@ucmerced.edu)
}

Received: 23 March 2014 - Published in Solid Earth Discuss.: 16 April 2014

Revised: 28 July 2014 - Accepted: 29 July 2014 - Published: 8 September 2014

\begin{abstract}
Recently, the potential for biochar use to recapture excess nutrients from dairy wastewater has been a focus of a growing number of studies. It is suggested that biochar produced from locally available excess biomass can be important in reducing release of excess nutrient elements from agricultural runoff, improving soil productivity, and longterm carbon $(C)$ sequestration. Here we present a review of a new approach that is showing promise for the use of biochar for nutrient capture. Using batch sorption experiments, it has been shown that biochar can adsorb up to $20-43 \%$ of ammonium and $19-65 \%$ of the phosphate in flushed dairy manure in $24 \mathrm{~h}$. These results suggest a potential of biochar for recovering essential nutrients from dairy wastewater and improving soil fertility if the enriched biochar is returned to soil. Based on the sorption capacity of 2.86 and $0.23 \mathrm{mg}$ ammonium and phosphate, respectively, per gram of biochar and $10-50 \%$ utilization of available excess biomass, in the state of California (US) alone, 11440 to 57200 tonnes of ammonium-N and 920-4600 tonnes of phosphate can be captured from dairy waste each year while at the same time disposing up to $8-40$ million tons of excess biomass.
\end{abstract}

\section{Background}

Finding sustainable and inexpensive methods for disposing of agricultural waste and byproducts is increasingly becoming a major environmental challenge worldwide. For example, even though the soil-fertility-related benefits of incorporating biomass into soil are indisputable, in some cases the biomass produced by modern farms and forestry operations significantly exceeds what can be locally incorporated into soil (Perlack et al., 2005). Similarly, the nutrient content of effluents from modern dairies and cattle feedlots far exceeds what can be safely dispersed in local pastures (Cao and Harris, 2010). In both cases, environmentally sound and sustainable means of disposal of the waste and other byproducts calls for transport of these materials off-site. Because this transport incurs significant economic cost, producers have little incentive to implement the practice. Managing for excess biomass from agricultural and forestry systems and excess nutrients from dairy farms thus poses multiple challenges to local and regional environmental managers in many parts of the world. However, both the organic matter in the excess biomass and the dairy manure have important resources and potential if used appropriately (Sarkhot et al., 2012, 2013; Yao et al., 2011; Ying et al., 2011; Hollister, 2011). Reusing these valuable resources to derive important benefits to local farms can help close an important resource utilization loop while improving soil productivity and long-term C sequestration (Biederman and Harpole, 2013). The use of biochar produced from excess biomass to extract valuable plant-essential nutrients from manure is a sustainable solution for agricultural waste disposal that is not just environmentally and ecologically sound, but it must also be economically viable for application in small- to large-scale agricultural production systems.

The approach reviewed here consists of two steps: (a) use of biochar produced from locally available excess biomass to recover the excess nutrients in the dairy wastewater, and (b) land application of the nutrient-enriched biochar to improve soil fertility and $\mathrm{C}$ sequestration. Combining these practices can reduce air pollution caused by biomass burning in open air and groundwater pollution caused by land application of dairy wastewater, which are currently the most common means of disposal of these waste materials. Many studies 
currently recommend biochar amendment for soil productivity and C sequestration (Lehmann et al., 2006; Glaser, 2002) and nutrient enrichment of coal using processes such as oxidative ammoniation (Berkowitz et al., 1970). However, these issues are rarely addressed in conjunction. Moreover, use of these practices has been limited by high cost and/or other considerations. At the same time, dairies worldwide are facing increasingly stringent government regulations to protect groundwater quality. The use of biochar for nutrient recovery from the dairy waste is currently noted for its potential to provide nutrient-enriched biochar for soil amendment (Sarkhot et al., 2012, 2013). In addition to provision of essential nutrients as enriched biochar, this approach is noted for its potential to improve the cost-effectiveness and acceptance of use and management of dairy manure or dairy wastewater. The terms "flushed dairy manure" or "dairy wastewater" refer to the common activity of cleaning cattle stalls by flushing water at high pressure, whereby the effluent is typically collected in sedimentation lagoons in the same or nearby dairy operations. Although we only review dairy wastewater in this paper, this approach can offer similar benefits for other agronomic pollutants, where excess plant nutrients are the main contaminants.

\section{Challenges and opportunities}

\subsection{Excess biomass}

In the US, the agriculture and forestry sectors alone generate nearly 1.3 billion dry tons of biomass per year (Perlack et al., 2005). At the present time, a portion of this excess biomass is burned to produce electricity, providing $3.7 \%$ of the US energy supply (Energy Information Administration, 2009). If it were utilized completely, this excess biomass could replace up to one-third of the transportation fuels used in US (Perlack et al., 2005). With current technologies, however, it is not feasible to use up all the excess biomass for generating energy. Some of the technological challenges include (a) low energy density of biomass and (b) scattered biomass sources that demand availability of small, local biomass power plants (Morris, 1999). As a result, most of the excess biomass is currently disposed of by burning and/or chopping of the residues and incorporating them into the soil. Biomass burning is not a desired approach for managing excess biomass mainly because of its negative effect on air pollution and release of harmful aerosols and greenhouse gases, with very little return unless the heat is used as a source of energy. Incorporating plant residues into soil has well-recognized benefits, including improvement of the soil physical and nutritional qualities and carbon sequestration. Some previous studies have reported that there is limited carbon sequestration potential from application of residue on soil, partly because of likely saturation of the soil's carbon storage potential and because most of the applied residue tends to accumulate in the pools of carbon that are most susceptible to decomposition and other losses (including leaching and/or erosion), traditionally referred to as the labile carbon fractions (Gulde et al., 2008; Hassink, 1997). Soil amendment with nitrogen-poor biomass sources, such as rice straw, has been noted in its potential to reduce $\mathrm{N}$ availability to plants by $\mathrm{N}$ immobilization. In addition, chopping and incorporation of excess biomass into soil is economically expensive (Morris, 1999) and the greenhouse gas emissions by the machinery used in the process potentially dwarf the short-term benefits.

A third, alternative means to dispose of excess biomass is controlled pyrolysis for energy production, which produces biochar (charcoal) as a byproduct (Rutberg et al., 2011; Wu et al., 2009; Manyà, 2012). Although the environmental benefits of this latter approach are well appreciated, it still remains a fairly expensive approach for many small-scale growers. The approach presented here describes a way of using the byproduct biochar for recapturing and transporting excess nutrients from dairy waste to soils. These value-added benefits of biochar will likely push controlled pyrolysis to become a major means to dispose of excess biomass.

\subsection{Excess nutrients in dairy waste}

Dairy operations generate wastewaters that are characterized by high concentrations of nitrogen $(\mathrm{N})$, phosphorous $(\mathrm{P})$, and other elements, Table 1 (McGarvey et al., 2005). Groundwater pollution caused by dairy wastewater is now a major environmental and health concern (Harter et al., 2002). Different technologies are now being developed and applied to reduce the nutrient load of dairy wastewater before it leaves the dairy operations. The conventional process for dairy wastewater treatment includes mechanical separation of solids and liquids, followed by sedimentation in lagoons to remove colloidal components in the liquid fraction, and finally disposal of the nutrient-rich water for irrigation. The use of dairy wastewater for irrigation purposes is a common practice that is utilized in practically every part of the world (Bouri et al., 2008; Bradford et al., 2003; Keraita et al., 2008; Majer Newman et al., 1999; Pattnaik et al., 2007; Ramirez-Fuentes et al., 2002; Shelef and Azov, 1996; Vymazal, 2007). The high nutrient concentrations of dairy wastewaters have made it a desired option for providing plant-essential nutrients for cultivated systems at relatively low cost.

However, concern is routinely raised about irrigation with dairy wastewater, as the high concentration of nutrients also poses a major threat to the groundwater quality downstream of farms and in the underlying aquifers. Naturally, most soils are negatively charged and therefore have low capacity to retain nutrient anions (e.g., nitrate). Consequently, after irrigation with dairy wastewater, anions in dairy water are readily leached out from the soil. In soils with low cation retention capacity (e.g., sandy soils) the cations face a similar fate. Furthermore, soils that have been fertilized for long periods can 
Table 1. Composition of dairy wastewater derived from lagoons in two dairy farms in the San Joaquin Valley, in Central California. Each farm at the time had about 800 Holstein milking cows and both lagoons had about 95 million L holding capacity. The lagoon where the samples for the circulated wastewater were collected uses three circulators, while the stagnant lagoon was not outfitted with anything similar. The values reported are for samples that were collected over a year (McGarvey et al., 2005).

\begin{tabular}{llll}
\hline \multirow{2}{*}{ Variable } & \multicolumn{2}{c}{ Range } & \multirow{2}{*}{ Unit } \\
\cline { 2 - 3 } & $\begin{array}{l}\text { Circulated } \\
\text { wastewater }\end{array}$ & $\begin{array}{l}\text { Stagnant } \\
\text { lagoon }\end{array}$ & \\
\hline Total Nitrogen $(\mathrm{N})$ & $6.3-15.6$ & $6.4-22.5$ & $\mathrm{mmol} \mathrm{L}^{-1}$ \\
Ammonia $\left(\mathrm{NH}_{3}\right)$ & $9.5-12.1$ & $4.5-19.1$ & $\mathrm{mmol} \mathrm{L}^{-1}$ \\
Nitrate $\left(\mathrm{NO}_{3}\right)$ & nd & nd & $\mathrm{mmol} \mathrm{L}^{-1}$ \\
Nitrite $\left(\mathrm{NO}_{2}\right)$ & nd & nd & $\mathrm{mmol} \mathrm{L}^{-1}$ \\
Sulfate $\left(\mathrm{SO}_{4}\right)$ & $0.41-0.82$ & $0.13-1.39$ & $\mathrm{mmol} \mathrm{L}^{-1}$ \\
Sodium $\left(\mathrm{Na}^{2}\right)$ & $5.7-7.0$ & $2.0-7.7$ & $\mathrm{mmol} \mathrm{L}^{-1}$ \\
Calcium $(\mathrm{Ca})$ & $2.8-6.5$ & $1.7-7.2$ & $\mathrm{mmol} \mathrm{L}^{-1}$ \\
Phosphorous $(\mathrm{P})$ & $1.1-1.5$ & $0.7-2.0$ & $\mathrm{mmol} \mathrm{L}^{-1}$ \\
Potassium $(\mathrm{K})$ & $0.6-2.4$ & $0.3-1.7$ & $\mathrm{mmol} \mathrm{L}^{-1}$ \\
$\begin{array}{l}\text { Dissolved solids } \\
\text { Electrical }\end{array}$ & $2530-2890$ & $1217-4038$ & $\mathrm{mg} \mathrm{L}^{-1}$ \\
conductivity $(\mathrm{EC})$ & $3.6-4.4$ & $1.8-7.4$ & $\mathrm{dS} \mathrm{m}$ \\
pH & & & \\
\hline
\end{tabular}

nd = not-detected, below detection

have limited ability to absorb nutrients from wastewater due to saturation of ion exchange sites.

The University of California (Harter et al., 2012) recently conducted an extensive review of groundwater pollution by agriculturally derived nitrate. The study area covers four California counties, which are in the top five for the highest agricultural production in the US and account for half of the state's dairy herd. The study showed that land-applied dairy manure adds $127 \mathrm{Gg} \mathrm{N} \mathrm{yr}^{-1}$ to farmlands, with a large fraction of it leaching to the underlying groundwater. Furthermore, the study reported that $57 \%$ of the current population depends on groundwater with pre-treatment nitrate levels that exceeded the maximum safe level set by the state (45 $\mathrm{mg} \mathrm{L}^{-1}$ ) at least once between 2006 and 2010. The affected population could reach $80 \%$ by 2050 .

The Manure Technology Feasibility Assessment Panel, instituted by the California Air Resources Board (CARB), compared 44 different manure management technologies including thermal conversion and anaerobic digestion (California Air Resources Board; CARB, 2005). According to the report, many of the available technologies were not suitable for flushed manure (liquid), which is the most common waste product from dairy farms in California (80\% of dairy farms), Florida and many other regions in the US and around the world. Very few of the techniques could remove salt or phosphorus from the liquid dairy waste, which can pose a risk of eutrophication even at low concentrations. The CARB panel reported that the technologies capable of phosphorus reduction and salt isolation had high initial and operating costs. For example, nitrification/denitrification systems, which can reduce phosphorus in the wastewater, can cost up to USD 600 per cow for construction. With an average herd size of 824 in California (California Dairy Statistics, 2008), this cost can be close to half a million dollars per farm. Recent studies have demonstrated the potential of bioremediation methods, such as constructed wetlands, for removal of nutrients from the dairy wastewater (Moir et al., 2005). However, these methods are not consistently effective under wide range of climates and management practices (Majer Newman et al., 1999). In addition, several of the biological treatment systems have limitations related to low cleanup efficiency in winter, low phosphorous removal capacity unless additional sorbents are used (Vymazal, 2007; Brix, 1993), and potential to create a (semi)permanent sink of essential nutrients in the wetland plants.

From the foregoing discussions it is apparent that there is a need for efficient, low-cost, and multipurpose alternative solutions for managing excess biomass and dairy wastewater. The use of biochar to recover nutrients from excess dairy waste addresses both these challenges. This approach uses biochar produced from excess biomass (preferably as a byproduct of bioenergy generation) as a vehicle to transport excess nutrients from dairy waste to low quality soils. The concept capitalizes on the well-documented sorption capacity and soil conditioning potential of biochar. To illustrate the plausibility of this approach, we provide data from a laboratory experiment as well as the dairy industry and excess agricultural waste data from the state of California.

\section{Biochar as soil amendment}

\subsection{Nature and properties of biochar}

Biochar is a product of biomass pyrolysis (combustion in oxygen-limited environment). It is highly resistant to microbial decomposition and can facilitate sequestration of carbon for hundreds of years up to millennia when added to soil (Lehmann et al., 2006; Schmidt and Noack, 2000). Biochar has the capacity to adsorb cations, anions as well as nonpolar organic compounds (Gürüz, 1980; Fujita et al., 1991; Sander and Pignatello, 2005). The sorption capacity, porosity and other physical properties vary depending on the pyrolysis temperature and type of biomass used as feedstock (Lehmann, 2007; Downie et al., 2009). Although many recent studies have demonstrated the potential of biochar for $\mathrm{C}$ sequestration and improvement of soil productivity (Biederman and Harpole, 2013; Sarkhot et al., 2012), potential of biochar for contaminant remediation is only recently gaining growing attention (Beesley et al., 2011; Cao and Harris, 2010). The high sorption capacity of biochar suggests 
potential of removing various inorganic and organic pollutants from solution. Lehmann (2007) reported that biochar can adsorb $>3000 \mathrm{mg} \mathrm{kg}^{-1}$ phosphates, even at low solution concentrations of $40 \mathrm{mg} \mathrm{L}^{-1}$, whereas soils with low native $\mathrm{P}$ content (no biochar amendment) could only adsorb about $600 \mathrm{mg} \mathrm{kg}^{-1}$ phosphates. This high sorption capacity of biochar can be particularly beneficial for removal of nutrient contaminants, which are valuable but misplaced resources.

\subsection{Benefits of biochar as a soil conditioner}

The United Nations Convention to Combat Desertification and other organizations have supported biochar application as a sustainable land management strategy (United Nations Convention to Combat Desertification, 2009) for different types of soils and production systems around the world, as it has been shown to significantly improve the soil productivity (Biederman and Harpole, 2013). The improvement is attributed to the high cation and anion exchange capacity of biochar as well as its positive influence on soil structure and microbial dynamics (Glaser, 2002; Liang et al., 2006). Biochar has been shown to reduce gaseous and leaching losses of $\mathrm{C}$ and $\mathrm{N}$ from soil (Sarkhot et al., 2012; Laird et al., 2010). Furthermore, it was shown that biochar can sorb more than $5 \mathrm{mg} \mathrm{NH}_{4}^{+}$and $0.2 \mathrm{mg} \mathrm{PO}_{4}^{3-}$ per gram of biochar from solution (including dairy wastewater) enabling retention of these plant-essential nutrients in the soil (Sarkhot et al., 2013). Several students have shown that nutrients and water retained by biochar slowly become available to plants as a result of decomposition of the char and changes in soil $\mathrm{pH}$ due to char application (Spokas et al., 2012; Biederman and Harpole, 2013).

In addition to retaining $\mathrm{N}$ and $\mathrm{P}$, the Brazilian Terra Preta soils are an excellent example of the potential of biochar in improving the long-term productivity of soils (Glaser et al., 2001). Coal-derived humic substances have also been reported to improve soil physical properties such as aggregation and moisture retention (Mbagwu and Piccolo, 1997; Piccolo et al., 1996). Piccolo et al. (1996) reported that coal-derived humic acids improved rates of water infiltration and aggregate stability even at small rates of addition $\left(1.5 \mathrm{Mg} \mathrm{ha}^{-1}\right)$. Although some authors reported mixed effects of biochar addition on soil aggregation (Busscher et al., 2010), the preferential occurrence of char particles in aggregates (Brodowski et al., 2006), positive effect of biochar on soil microbial communities (Thies and Rillig, 2009) and reduction in soil penetration resistance due to char addition (Busscher et al., 2010) suggest that biochar amendment can improve the soil physical properties in the long term. Glaser (2002) suggested that this would allow retention of nutrient ions like $\mathrm{NO}_{3}^{-}$that are not usually retained in soil.

\subsection{Constraints in biochar application}

Although soil application of biochar has been shown to have multiple benefits, much effort is needed to make this an economically viable practice. Economic analysis of industrialscale fast and slow pyrolysis plants showed that the cost of pyrolysis and transportation were higher than the value obtained from electricity and biochar sale (McCarl et al., 2009). The authors reported that a $75 \%$ reduction in feedstock cost (USD $45 \mathrm{t}^{-1}$ ) would be necessary for the fast pyrolysis to be profitable, while a USD $11 \mathrm{t}^{-1}$ subsidy would be necessary to make the slow pyrolysis profitable. Farm-scale energy production systems (e.g., ethanol, pyrolysis) are suggested as a way to reduce the carbon costs associated with biomass transport to large energy production plants. Joseph (2009) showed that, at a small scale, biochar conversion projects could be financially viable only by injection of additional income from carbon credits, higher crop yields, and reduced household medical expenses due to improvement in indoor air quality with the use of improved biochar stoves, etc. The use of biochar as a nutrient-recapturing medium and the consequent savings in chemical fertilizers could potentially improve the viability of such small-scale conversion setups.

\section{Biochar and dairy pollution: closing the loop}

Innovative alternatives are critically needed to make the biomass disposal and dairy wastewater management economically sustainable. The use of biochar to recover excess nutrients from daily waste and agricultural runoff in general is one such alternative that connects these two disparate and individually pressing environmental issues (Fig. 1). There are two aspects of this approach: (a) capturing the excess nutrients in dairy wastewater using biochar produced from locally available excess biomass and (b) using the nutrient-enriched biochar to improve soil productivity and carbon sequestration.

The black and red pathways in Fig. 1 show the major current practices of dairy waste and biomass disposal as well as the environmental consequences of these practices, such as loss of nutrients from the ecosystem and air pollution described in detail in the following sections. The green pathways show the new approach and the environmental benefits that it can offer. By following the green pathways, the red pathways are eliminated to various degrees. This method is an integrative solution, where biochar is used as a means to (a) recapture excess nutrients from common agricultural pollutants such as dairy wastewater in order to reduce groundwater pollution, (b) transport the captured nutrients to lowquality soils, where it can be used to supply essential nutrients and improve soil physical conditions, (c) improve $\mathrm{CO}_{2}$ sequestration potential of agricultural soils, and (d) dispose of excess biomass from agriculture and forestry in an environmentally and economically sustainable manner (Sarkhot 


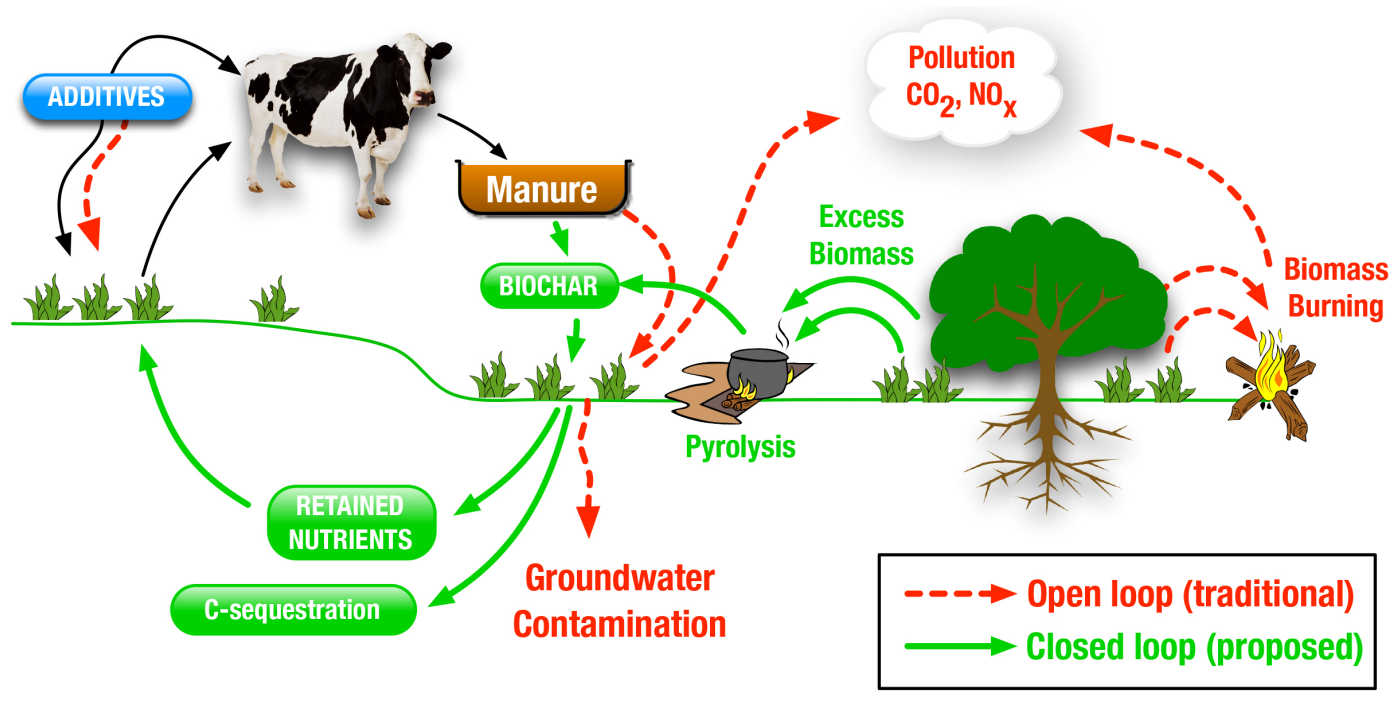

Figure 1. Schematic representation of the components and overarching goal of the approach to use biochar to extract nutrients from dairy wastewater.

et al., 2012, 2013). While the above benefits are individually attractive in addressing important contemporary environmental challenges, the benefit of addressing these disparate challenges concurrently (as a system) can be more than the sum of benefits accrued by addressing them individually.

This approach can enhance the positive effects of biochar on soil productivity and address environmental concerns regarding groundwater pollution by the dairy industry. Although activated carbon is widely used in water and air filtration, to the best of our knowledge, no studies have reported the potential of biochar to recover and reuse the excess nutrients. Therefore, we conducted a proof-of-concept lab experiment to test the potential of biochar to recapture excess nutrients from flushed dairy manure.

\subsection{Nutrient recovery potential of biochar: illustrative examples}

The data presented in Fig. 2 was derived using commercialgrade biochar that was produced by pyrolysis of a mixture of hardwoods at $300^{\circ} \mathrm{C}$ (http://www.buyactivatedcharcoal. $\mathrm{com} /$ ). The flushed dairy manure was collected from the sedimentation lagoon at the Vander Woude dairy farm in Merced County, California. The manure was centrifuged and filtered through a $0.45 \mu \mathrm{m}$ filter to remove the colloidal particles. Sorption experiments were done using $10-100 \%$ of the manure in $0.001 \mathrm{M} \mathrm{CaCl}_{2}$ and biochar at the rate of $2 \mathrm{~g}$ per $40 \mathrm{~mL}$ solution. Samples were shaken for $24 \mathrm{~h}$, centrifuged, filtered through $0.45 \mu \mathrm{m}$ filter and the anion and cation concentrations were measured on Dionex ICS-2000 ReagentFree Integrated Ion Chromatography System. We found that 20 to $43 \%$ of the ammonium was removed from the dairy wastewater by biochar (Fig. 2), suggesting that this approach can be effective even for short treatment duration. In case of phosphorus, 19 to $65 \%$ of the phosphate was adsorbed by biochar.

The nutrient removal efficiency reported here is comparable to other techniques proposed for dairy wastewater treatment. For example, Ibekwe et al. (2003) reported $16 \%$ removal of ammonia and $33 \%$ removal of phosphate by a constructed wetland in California. On average, the constructed wetlands have been reported to remove $40-60 \%$ of the total $\mathrm{P}$ and $40-55 \%$ of the total N (Vymazal, 2007). Some of the proposed techniques for wastewater treatment have shown very high nutrient removal potential. In Hawaii, a multi-soillayer system with perlite, leilehua soil, honouliuli soil, sawdust, charcoal and iron fillings was reported to remove up to $96 \%$ of the inorganic N and up to $99 \%$ of the phosphate (Pattnaik et al., 2007). However, these systems are complicated and are not easily or economically applicable everywhere.

Based on the sorption capacity observed in this study $(0.23 \mathrm{mg}$ phosphate and $2.86 \mathrm{mg}$ ammonium per gram of biochar in $24 \mathrm{~h}$ at high manure concentration), biochar amendment at the rate of ten tons ha ${ }^{-1}$ can add $28.6 \mathrm{~kg} \mathrm{ha}^{-1}$ ammonium-N and $2.3 \mathrm{~kg} \mathrm{ha}^{-1}$ phosphate-P to soil. As a reference, sweet corn production in California requires $224 \mathrm{~kg} \mathrm{ha}^{-1} \mathrm{~N}$ for early spring plantings or $112 \mathrm{~kg} \mathrm{ha}^{-1} \mathrm{~N}$ for later plantings and $44.8-56 \mathrm{~kg} \mathrm{ha}^{-1}$ of $\mathrm{P}$ (Smith et al., 2009), while ten tons of dairy compost adds $60 \mathrm{~kg} \mathrm{ha}^{-1}$ of total $\mathrm{N}$ and $78 \mathrm{~kg} \mathrm{ha}^{-1}$ of phosphate-P. At the above-mentioned low biochar application rate, biochar enriched with dairy wastewater can supply $10-25 \%$ of $\mathrm{N}$ and $5-10 \%$ of $\mathrm{P}$ needed for the growth of corn. Although the direct addition of nutrients is small, it is important to note that these added nutrients are more likely to be retained in soil, and not leach out of the soil system after the application of irrigation water, as do nutrient elements directly added as fertilizers (Vymazal, 2007). In 


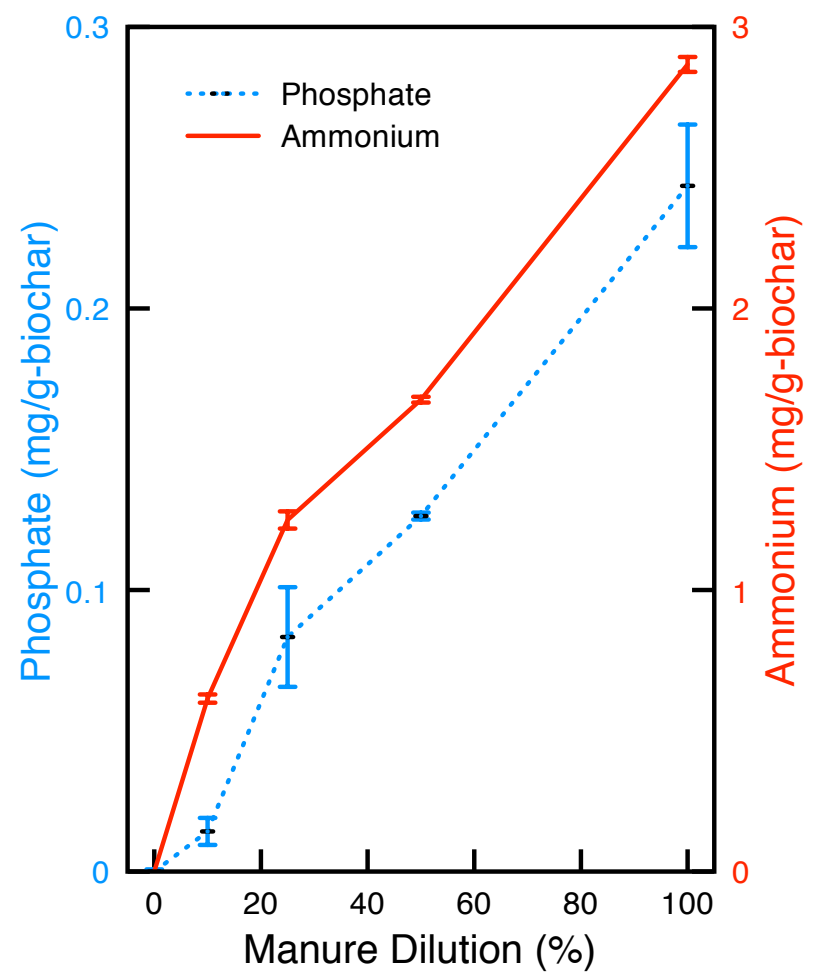

Figure 2. Recovery of ammonium and phosphate by biochar from dairy wastewater. Sorption experiments were done using biochar at the rate of $2 \mathrm{~g}$ per $40 \mathrm{~mL}$ solution. The experiment was conducted at manure dilutions of $10-100 \%$ of the manure in $0.001 \mathrm{M} \mathrm{CaCl}_{2}$ in order to capture the effect of nutrient concentration in manure on their recovery. Nutrient concentrations in manure can vary depending on the amount of water used to flush the manure, climate, and length of time the flushed manure has been stored in the lagoons (i.e., evaporative losses). The $100 \%$ concentration in this study equates to $714 \mathrm{mg} \mathrm{L}^{-1}$ ammonium and $24 \mathrm{mg} \mathrm{L}^{-1}$ phosphate, but higher concentrations are possible under different conditions. Error bars represent standard error where $n=4$ for each batch.

addition, the enriched biochar can also offer additional benefits of improving soil physical properties and further sorption potential for other essential nutrient ions.

\subsection{Effectiveness of the approach: California case study}

Here we use the state of California as an example to illustrate the potential benefits associated with using biochar for nutrient recovery and for improvement of soil quality. In California, more than 80 million bone dry tonnes (amount of wood at $0 \%$ moisture content) of waste biomass (Fig. 3) is produced every year (California Energy Commission, 2007). At the same time there are 1.8 million milk cows in the state of California (Fig. 4) producing about $225 \mathrm{~L} /$ cow/day flushed dairy manure (California Department of Food and Agriculture, 2008). Assuming 20 to $100 \%$ utilization of the waste biomass and $50 \%$ conversion efficiency, $8-40$ million tonnes

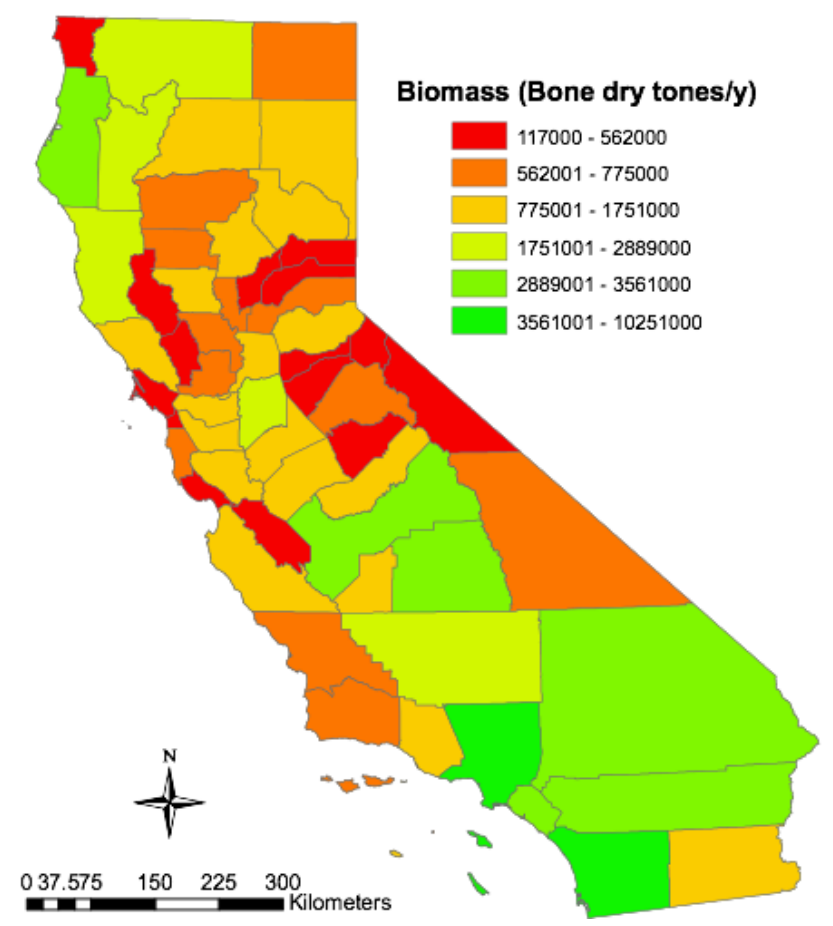

Figure 3. Amount of biomass produced annually in counties in the state of California, US (Commission, 2007).

(metric) of biomass can be disposed of while generating 420 million tonnes of biochar every year (Fig. 5). Based on the adsorption capacity shown in Fig. 2, this would allow for the capture of 11 440-57 200 tonnes of ammonia and 920-4600 tonnes of phosphate each year (Fig. 5). Assuming average US prices in 2010 for urea and triple super phosphate (NASS USDA, 2010), it can save up to USD 2 to 9.2 million in $\mathrm{N}$ fertilizer and USD 0.2 to 0.9 million in P fertilizer use per year. Furthermore, as shown in Fig. 6 the state-wide Californian $\mathrm{N}$ capture potential is compared with $\mathrm{N}$ released from cows where roughly $10 \%$ of the 240 kton of $\mathrm{N}$ that is applied to soil as flushed manure can be captured by biochar as $\mathrm{NH}_{4}$ (UC Committee of Experts on Dairy Manure Management, 2006). In this calculation, the potential for capturing organic $\mathrm{N}$ with biochar was not evaluated, but is very likely to also contribute to the capture of $\mathrm{N}$ from dairy manure using biochar.

\subsection{Value-added benefits of biochar as soil conditioner}

Using biochar as a soil amendment has been reported to reduce nutrient leaching in the field as well as emissions of other greenhouse gases such as methane and nitrous oxides from the soil (Lehmann et al., 2003; Renner, 2007; Sarkhot et al., 2012, 2013). For example, Sarkhot et al. (2012) found that relative to unamended soil, amendment of sandy soils from almond orchards in Merced Country, CA (with biochar as is and biochar that was enriched with nutrients from excess 


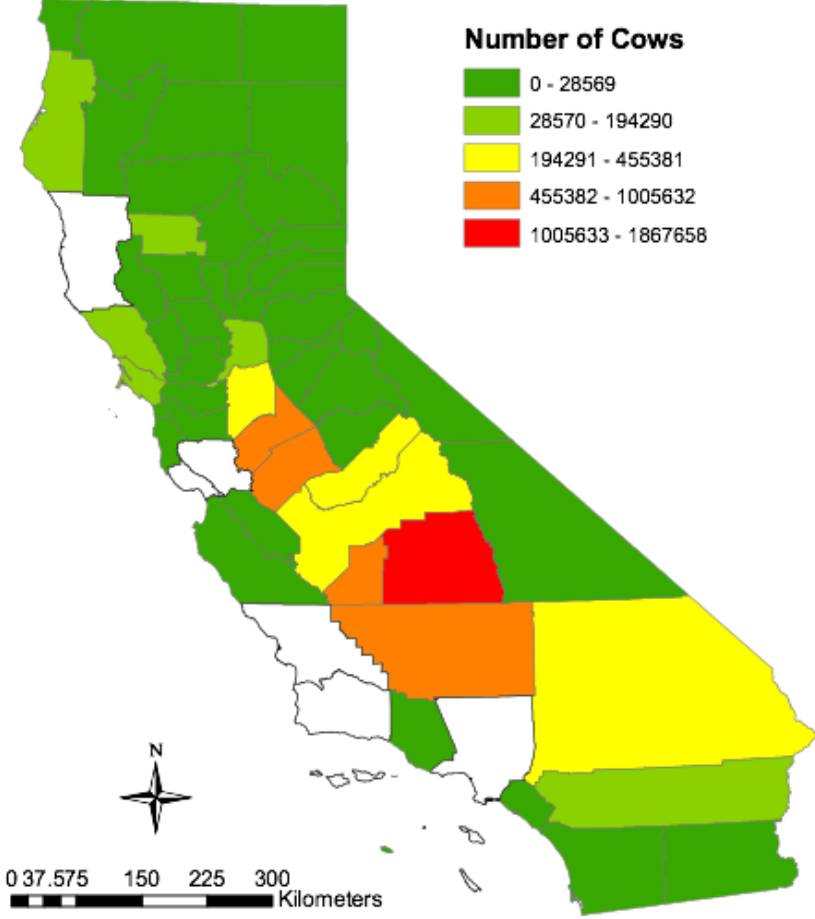

Figure 4. The number and distribution of live cows in California farms in counties (California Department of Food and Agriculture, 2008).

dairy waste) resulted in 68 and $75 \%$ reduction in net nitrification, 221 and $229 \%$ reduction in net ammonification, 67 and $68 \%$ reduction in cumulative $\mathrm{CO}_{2}$ flux, respectively, and a $26 \%$ reduction in cumulative $\mathrm{N}_{2} \mathrm{O}$ flux from these agricultural soils. These benefits can further enhance the effectiveness of this practice, though further studies are necessary to quantify the economic benefits related to water quality improvement and reduction in emissions. Use of biochar may also help in reducing unpleasant odors associated with application of dairy waste products. The US dairies usually have integrated feed production farms and the waste biomass from these farms, such as corn cobs or biomass from nearby farms, can offer a low cost, local source of biochar. Energy generated from pyrolysis and the valuable byproducts including syngas, bio-oil and industrial compounds such as meat browning and wood preservatives (Czernik and Bridgwater, 2004) can further reduce the cost of biochar production.

Studies show that a majority of the $\mathrm{N}$ in manure is in the form of organic $\mathrm{N}$ and ammonium (Mathews et al., 2001). A review of dairy effluent characteristics in New Zealand reported that nitrate concentrations were $6 \mathrm{ppm}$ or less in the studies reviewed ( $<3 \%$ of total N) (Longhurst et al., 2000). Nitrification occurs after the manure is applied to the soil (Van Horn et al., 2003). Since nitrate is not retained on the soil exchange complex and nitrate leaching is a major environmental concern for the dairies worldwide, using biochar to remove/reduce the ammonia and organic $\mathrm{N}$ in the manure

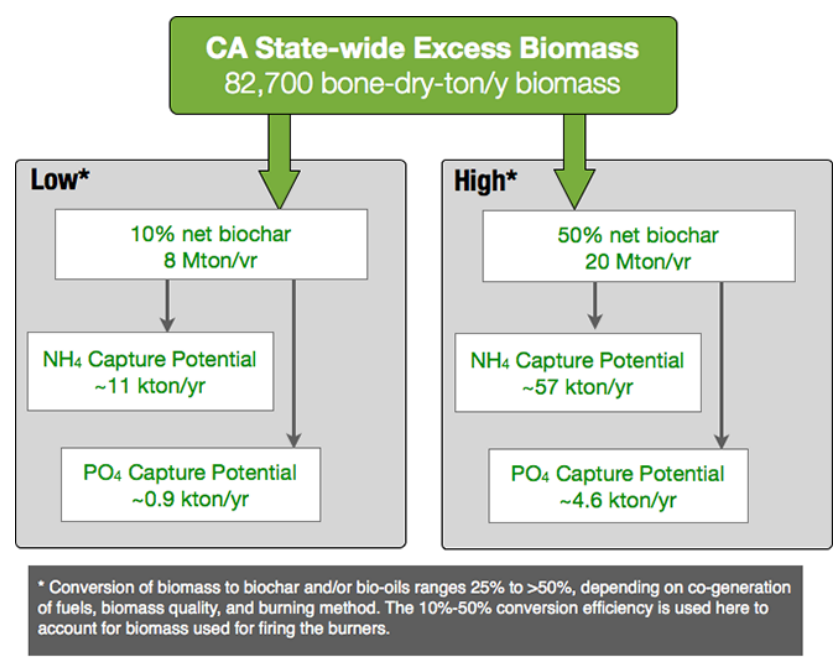

Figure 5. Potential of using biochar for recovering $\mathrm{N}$ and $\mathrm{P}$ from flushed dairy manure.

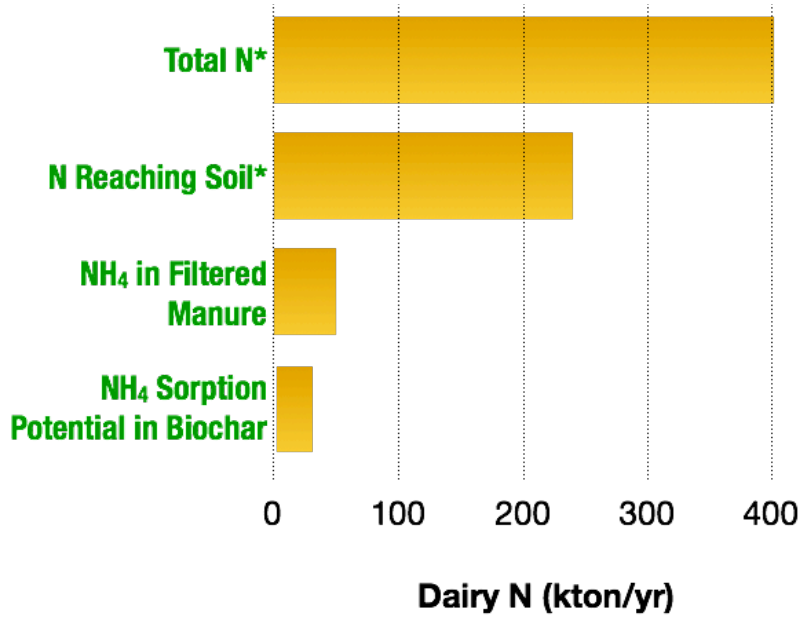

Figure 6. Total $\mathrm{N}$ and $\mathrm{N}$ reaching the soil estimates derived from a report from the University of California Agriculture and Natural Resources (UC Committee of Experts on Dairy Manure Management, 2006).

before it is applied to the soil can significantly improve the nutrient retention.

Nutrient enrichment of biochar can also alleviate the risk of nitrogen immobilization after application of biochar. For example, biochar with high volatile matter (VM) content was reported to cause a reduction in plant growth when applied to soil due to high microbial activity and $\mathrm{N}$ immobilization (Deenik et al., 2008). In addition, application of high VM biochar was found to lead to a decline in soil $\mathrm{NH}_{4}$ content after a 14-day incubation. Though the low VM biochar also led to decline in soil $\mathrm{NH}_{4}$ content, the effect was much smaller. Biochar produced at low temperature $\left(350^{\circ} \mathrm{C}\right)$ was also reported to have a negative effect on plant growth due to $\mathrm{N}$ immobilization (Gundale and DeLuca, 2007). On the 
other hand, applying biochar along with fertilizer has been reported to significantly improve the yields (Lehmann et al., 2003). These findings suggest that using enriched biochar can solve problems of reduced $\mathrm{N}$ availability.

\section{Knowledge gaps}

At present, there are some knowledge gaps and engineering challenges that need to be addressed to make this approach even more useful. Additional data and knowledge of biochar properties such as maximum adsorption and retention capacity for various nutrients is necessary in order to ensure efficient use of biochar with different properties. Bioavailability of the adsorbed nutrients, rate of nutrient release upon soil application of biochar, effect of storage on nutrient bioavailability as well as the effect of nutrient enrichment on longterm stability of biochar are a few other important topics that need further study.

Some of the potential ways of using biochar for nutrient recovery can include using biochar bed or vertical biochar screens in the sedimentation lagoons, a filtration device prior to the use of wastewater for irrigation, incorporating biochar into the bed of constructed wetlands or as a bedding material in the dairy barns. Research is needed to develop effective and economical systems that can be integrated into the existing farm structures and to quantify the parameters required for designing these systems. However, the multiple benefits outlined here suggest that the economic and environmental potential of this approach would justify efforts to address these knowledge gaps.

Furthermore, careful analysis is warranted to determine that the biochar used for improving soil plant productivity does not lead to the introduction of harmful compounds into soil and the food chain. Of particular concern is that, depending on the production conditions; biochar may contain high concentrations of polycyclic aromatic hydrocarbons (PAHs) (Hilber et al., 2012; Quilliam et al., 2013). The PAHs are persistent organic pollutants that are byproducts of incomplete combustion of fossil fuel and exhibit toxic, mutagenic and carcinogenic properties (Chen and Liao, 2006). Studies have shown that biochar contains considerable amounts of PAHs and the high sorptive capacity of biochar can also further promote persistence of PAHs in the biosphere (Quilliam et al., 2013). Hence, before the introduction of any large-scale work with biochar, careful work is needed to minimize the amount of PAHs that are introduced to the soil with biochar application and the risks associated with biochar use.

\section{Conclusions}

The global environmental challenges faced by the current and future generations are myriad in their origin and impact. The potential mitigation solutions are often economically expensive and/or have their own environmental con- sequences. For example, the benefit of biofuels for reducing fossil fuel consumption can easily be offset by greenhouse gas emissions during feedstock production - unless produced from waste biomass or from feedstock grown on degraded land (Fargione et al., 2008). Therefore it can be argued that for any potential mitigation approach to succeed in the long run, it should meet the following minimum requirements: (a) it must be able generate revenues to cover its cost, and (b) it should have minimal negative effects on the environment throughout its life cycle. In this regard, multipurpose solutions that can address more than one environmental concern are particularly attractive, as they have a higher likelihood of meeting these requirements. The use of biochar enriched with excess dairy waste in agricultural operations meets the above-mentioned requirements of a lowcost, revenue-generating solution with minimal environmental impacts. The use of biochar to capture the excess nutrients in common agricultural pollutants such as dairy wastewater followed by soil application of enriched biochar can offer an economical solution for disposing of excess biomass as well as for reducing the nutrient load from dairy farms while improving nutrient content, nutrient holding capacity and carbon sequestration capacity of soil. An agronomic system based on pyrolysis of locally available waste biomass treated and used in the same area to avoid transportation costs can be a multipurpose and cost-effective means of incorporating biochar into existing agricultural scenarios. The greenhouse gas reduction (e.g., carbon dioxide, methane, nitrous oxides) and reduction in nutrient leaching due to soil application of biochar are important environmental benefits of this approach.

Acknowledgements. We thank Simon Vander Woude of Vander Woude dairy farm and Alejandro R. Castillo from California Cooperative Extension for assistance in obtaining dairy manure used in this study. The work was funded by startup funds from UC Merced to AAB.

Edited by: G. Gascó

\section{References}

Beesley, L., Moreno-Jiménez, E., Gomez-Eyles, J. L., Harris, E., Robinson, B., and Sizmur, T.: A review of biochars' potential role in the remediation, revegetation and restoration of contaminated soils, Environ. Pollut., 159, 3269-3282, 2011.

Berkowitz, N., Chakrabartty, S. K., Cook, F. D., and Fujikawa, J. I.: On Agrobiological Activity of Oxidatively Ammoniated Coal, Soil Sci., 110, 211-217, 1970.

Biederman, L. A. and Harpole, W. S.: Biochar and its effects on plant productivity and nutrient cycling: a meta-analysis, GCB Bioenergy, 5, 202-214, doi:10.1111/gcbb.12037, 2013.

Bouri, S., Abida, H., and Khanfir, H.: Impacts of wastewater irrigation in arid and semi arid regions: case of Sidi Abid region, Tunisia, Environ. Geol., 53, 1421-1432, 2008. 
Bradford, A., Brook, R., and Hunshal, C.: Wastewater irrigation in Hubli-Dharwad, India: Implications for health and livelihoods, Environ. Urban., 15, 157-170, 2003.

Brix, H.: Wastewater treatment in constructed wetlands: system design, removal processes, and treatment performance, in: Constructed Wetlands for Water Quality Improvement, edited by: Moshiri, G. A., Lewis Publishers, Boca Raton, FL, USA, 9-22, 1993.

Brodowski, S., John, B., Flessa, H., and Amelung, W.: Aggregateoccluded black carbon in soil, Eur. J. Soil Sci., 57, 539-546, 2006.

Busscher, W. J., Novak, J. M., Evans, D. E., Watts, D. W., Niandou, M. A. S., and Ahmedna, M.: Influence of Pecan Biochar on Physical Properties of a Norfolk Loamy Sand, Soil Sci., 175, 10-14, 2010

California Air Resources Board (CARB): An Assessment of Technologies for Management and Treatment of Dairy Manure in California's San Joaquin Valley. Prepared by the San Joaquin Valley Dairy Manure Technology Feasibility Assessment Panel, 2005.

California Dairy Statistics, California Department of Food and Agriculture (Milk and Dairy Foods Safety Branch), 2008.

California Department of Food and Agriculture: California Dairy Statistics, California Department of Food and Agriculture, Milk and Dairy Foods Safety Branch, Sacramento, CA, 2008.

Cao, X. and Harris, W.: Properties of dairy-manure-derived biochar pertinent to its potential use in remediation, Bioresour. Technol., 101, 5222-5228, 2010.

Chen, S. and Liao, C.: Health risk assessment on human exposed to environmental polycyclic aromatic hydrocarbons pollution sources, Sci. Total Environ., 366, 112-123, 2006.

Commission, C. E.: An Assessment of Biomass Resources in California, California Energy Commission, Sacramento, CA, 2007.

Czernik, S. and Bridgwater, A. V.: Overview of applications of biomass fast pyrolysis oil, Energ. Fuels, 18, 590-598, 2004.

Deenik, J. L., Uehara, G., Sumiyoshi, Y., Sidibe, A., McClellan, A., and Antal, M.: Charcoal Volatile Matter content and its effects on plant growth and biological properties of an infertile tropical soil, Joint Annual Meeting of GSA, ASA-CSSA-SSSA and GCAGS, 2008

Downie, A., Crosky, A., and Munroe, P.: Physical properties of biochar, in: Biochar for Environmental Management: Science and Technology, edited by: Lehmann, J. and Joseph, S., Earthscan, Sterling, VA, USA, 13-32, 2009.

Energy Information Administration: Renewable Energy Consumption and Electricity Preliminary Statistics 2008, available at: http://www.eia.doe.gov/cneaf/alternate/page/renew_energy_ consump/rea_prereport.html (last access: 27 April 2010), 2009.

Fargione, J., Hill, J., Tilman, D., Polasky, S., and Hawthorne, P.: Biofuels: Effects on land and fire - Response, Science, 321, 199_ 200, 2008.

Fujita, I., Tomooka, J., and Sugimura, T.: Sorption of anionic surfactants with wood charcoal, B. Chem. Soc. Jpn., 64, 738-740, 1991.

Glaser, B., Haumaier, L., Guggenberger, G., and Zech, W.: The "Terra Preta" phenomenon: A model for sustainable agriculture in the humid tropics, Naturwissenschaften, 88, 37-41, 2001.

Glaser, B.: Ameliorating physical and chemical properties of highly weathered soils in the tropics with charcoal - A review, Biol. Fert. Soils, 35, 219-230, 2002.
Gulde, S., Chung, H., Amelung, W., Chang, C., and Six, J.: Soil carbon saturation controls labile and stable carbon pool dynamics, Soil Sci. Soc. Am. J., 72, 605-612, 2008.

Gundale, M. J. and DeLuca, T. H.: Charcoal effects on soil solution chemistry and growth of Koeleria macrantha in the ponderosa pine/Douglas-fir ecosystem, Biol. Fert. Soils, 43, 303-311, 2007.

Gürüz, K.: Oxy-ammoniation of Elbistan lignite to produce a nitrogenous fertilizer, Fuel, 59, 772-776, 1980.

Harter, T., Davis, H., Mathews, M. C., and Meyer, R. D.: Shallow groundwater quality on dairy farms with irrigated forage crops, J. Contam. Hydrol., 55, 287-315, 2002.

Harter, T., Lund, J. R., Darby, J., Fogg, G. E., Howitt, R., Jessoe, K. K., Pettygrove, G. S., Quinn, J. F., Viers, J. H., Boyle, D. B., Canada, H. E., DeLaMora, N., Dzurella, K. N., Fryjoff-Hung, A., Hollander, A. D., Honeycutt, K. L., Jenkins, M. W., Jensen, V. B., King, A. M., Kourakos, G., Liptzin, D., Lopez, E. M., Mayzelle, M. M., McNally, A., Medellin-Azuara, J., and Rosenstock, T. S.: Addressing Nitrate in California's Drinking Water with a Focus on Tulare Lake Basin and Salinas Valley Groundwater. Report for the State Water Resources Control Board Report to the Legislature. Center for Watershed Sciences, University of California, Davis, 78 pp., http://groundwaternitrate.ucdavis.edu, 2012.

Hassink, J.: The capacity of soils to preserve organic $\mathrm{C}$ and $\mathrm{N}$ by their association with clay and silt particles, Plant Soil, 191, 7787, 1997.

Hilber, I., Blum, F., Leifeld, J., Schmidt, H.-P., and Bucheli, T. D.: Quantitative Determination of PAHs in Biochar: A Prerequisite To Ensure Its Quality and Safe Application, J. Agr. Food Chem., 60, 3042-3050, doi:10.1021/jf205278v, 2012.

Hollister, C. C.: Ammonium, Nitrate and Phosphate Sorption to Water-Rinsed and Non-Rinsed Biochars, Cornell University, 2011.

Ibekwe, A. M., Grieve, C. M., and Lyon, S. R.: Characterization of microbial communities and composition in constructed dairy wetland wastewater effluent, Appl. Environ. Microbiol., 69, 5060-5069, 2003.

Joseph, S.: Socio-economic assessment and implementation of small-scale biochar projects, in: Biochar for environmental management: Science and Technology, edited by: Lehmann, J. and Joseph, S., Earthscan, Sterling, VA, USA, 359-374, 2009.

Keraita, B., Jiménez, B., and Drechsel, P.: Extent and implications of agricultural reuse of untreated, partly treated and diluted wastewater in developing countries, $\mathrm{CAB}$ reviews: Perspectives in agriculture, veterinary science, nutrition and natural resources, 3, 1-15, 2008.

Laird, D., Fleming, P., Wang, B., Horton, R., and Karlen, D.: Biochar impact on nutrient leaching from a Midwestern agricultural soil, Geoderma, 158, 436-442, 2010.

Lehmann, J.: Bio-energy in the black, Front. Ecol. Environ., 5, 381387, 2007.

Lehmann, J., Pereira da Silva, J., Steiner, C., Nehls, T., Zech, W., and Glaser, B.: Nutrient availability and leaching in an archaeological Anthrosol and a Ferralsol of the Central Amazon basin: fertilizer, manure and charcoal amendments, Plant Soil, 249, 343-357, 2003.

Lehmann, J., Gaunt, J., and Rondon, M.: Bio-char sequestration in terrestrial ecosystems - A review, Mitigation and Adaptation Strategies for Global Change, 11, 403-427, 2006. 
Liang, B., Lehmann, J., Solomon, D., Kinyangi, J., Grossman, J., O’Neill, B., Skjemstad, J. O., Thies, J., Luizao, F. J., Petersen, J., and Neves, E. G.: Black carbon increases cation exchange capacity in soils, Soil Sci. Soc. Am. J., 70, 1719-1730, 2006.

Longhurst, R. D., Roberts, A. H. C., and O’Connor, M. B.: Farm dairy effluent: A review of published data on chemical and physical characteristics in New Zealand, New Zeal. J. Agr. Res., 43, 7-14, 2000.

Majer Newman, J., Clausen, J. C., and Neafsey, J. A.: Seasonal performance of a wetland constructed to process dairy milkhouse wastewater in Connecticut, Ecol. Eng., 14, 181-198, 1999.

Manyà, J. J.: Pyrolysis for Biochar Purposes: A Review to Establish Current Knowledge Gaps and Research Needs, Environ. Sci. Technol., 46, 7939-7954, doi:10.1021/es301029g, 2012.

Mathews, M. C., Frate, C., Harter, T., Sather, S., and Lagoon Water Composition, Sampling and Field Analysis, University of California Cooperative Extension, 2001.

Mbagwu, J. S. C. and Piccolo, A.: Effects of humic substances from oxidized coal on soil chemical properties and maize yield, in: The role of humic substances in the ecosystems and in environmental protection, edited by: Drozd, J., Gonet, S. S., Sensesi, N., and Weber, J., Polish Society of Humic Substances Wroclaw, Poland, 921-925, 1997.

McCarl, B., Peacocke, C., Chrisman, R., Kung, C., and Sands, R.: Economics of biochar production, utilization and greenhouse gas offsets, in: Biochar for environmental management, edited by: Lehmann, J. and Joseph, S., Earthscan, Stirling, VA, USA, 341358, 2009.

McGarvey, J., Miller, W., Sanchez, S., Silva, C., and Whitehand, L.: Comparison of bacterial populations and chemical composition of dairy wastewater held in circulated and stagnant lagoons, J. Appl. Microbiol., 99, 867-877, 2005.

Moir, S. E., Svoboda, I., Sym, G., Clark, J., McGechan, M. B., and Castle, K.: An experimental plant for testing methods of treating dilute farm effluents and dirty water, Biosyst. Eng., 90, 349-355, 2005.

Morris, G.: The Value of the Benefits of U.S. Biomass Power, Prepared for National Renewable Energy Laboratory, NREL/SR570-27541, 1999.

Pattnaik, R., Yost, R. S., Porter, G., Masunaga, T., and Attanandana, T.: Improving multi-soil-layer (MSL) system remediation of dairy effluent, Ecol. Eng., 32, 1-10, 2007.

Perlack, R. D., Wright, L. L., Turhollow, A. F., Graham, R. L., Stokes, B. J., and Erbach, D. C.: Biomass as Feedstock for a Bioenergy and Bioproducts Industry: The Technical Feasibility of a Billion-Ton Annual Supply, available at: http:// feedstockreview.ornl.gov/pdf/billion_ton_vision.pdf, 2005.

Piccolo, A., Pietramellara, G., and Mbagwu, J. S. C.: Effects of coal derived humic substances on water retention and structural stability of mediterranean soils, Soil Use Manag., 12, 209-213, 1996.

Quilliam, R. S., Rangecroft, S., Emmett, B. A., Deluca, T. H., and Jones, D. L.: Is biochar a source or sink for polycyclic aromatic hydrocarbon (PAH) compounds in agricultural soils?, GCB Bioenergy, 5, 96-103, doi:10.1111/gcbb.12007, 2013.
Ramirez-Fuentes, E., Lucho-Constantino, C., Escamilla-Silva, E., and Dendooven, L.: Characteristics, and carbon and nitrogen dynamics in soil irrigated with wastewater for different lengths of time, Bioresour. Technol., 85, 179-187, 2002.

Renner, R.: Rethinking biochar, Environ. Sci. Technol., 41, 59325933, 2007.

Rutberg, P. G., Bratsev, A. N., Kuznetsov, V. A., Popov, V. E., Ufimtsev, A. A., and Shtengel', S. V.: On efficiency of plasma gasification of wood residues, Biomass Bioenerg., 35, 495-504, doi:10.1016/j.biombioe.2010.09.010, 2011.

Sander, M. and Pignatello, J. J.: Characterization of charcoal adsorption sites for aromatic compounds: Insights drawn from single-solute and bi-solute competitive experiments, Environ. Sci. Technol., 39, 1606-1615, 2005.

Sarkhot, D. V., Berhe, A. A., and Ghezzeehei, T. A.: Impact of Biochar Enriched with Dairy Manure Effluent on Carbon and Nitrogen Dynamics, J. Environ. Qual., 41, 1107-1114, 2012.

Sarkhot, D. V., Ghezzehei, T. A., and Berhe, A. A.: Biochar for nutrient recapture from dairy wastewater: recovery of major nutrients, J. Environ. Qual., 42, 1545-1554 2013.

Schmidt, M. W. I. and Noack, A. G.: Black carbon in soils and sediments: Analysis, distribution, implications, and current challenges, Global Biogeochem. Cy., 14, 777-793, 2000.

Shelef, G. and Azov, Y.: The coming era of intensive wastewater reuse in the Mediterranean region, Water Sci. Technol., 33, 115$125,1996$.

Spokas, K. A., Cantrell, K. B., Novak, J. M., Archer, D. W., Ippolito, J. A., Collins, H. P., Boateng, A. A., Lima, I. M., Lamb, M. C., and McAloon, A. J.: Biochar: a synthesis of its agronomic impact beyond carbon sequestration, J. Environ. Qual., 41, 973989, 2012.

Thies, J. and Rillig, M.: Characteristics of biochar: Biological properties, in: Biochar for Environmental Management, edited by: Lehmann, J. and Joseph, S., Earthscan, London, 85-105, 2009.

UC Comittee of Experts on Dairy Manure Management: Groundwater Quality Protection: Managing Dairy Manure in the Central Valley (Publication 9004), University of California, Agr. Nat. Resour., 2006.

Vymazal, J.: Removal of nutrients in various types of constructed wetlands, Sci. Total Environ., 380, 48-65, 2007.

Wu, H., Yip, K., Tian, F., Xie, Z., and Li, C.-Z.: Evolution of Char Structure during the Steam Gasification of Biochars Produced from the Pyrolysis of Various Mallee Biomass Components, Ind. Eng. Chem. Res., 48, 10431-10438, doi:10.1021/ie901025d, 2009.

Yao, Y., Gao, B., Inyang, M., Zimmerman, A. R., Cao, X., Pullammanappallil, P., and Yang, L.: Removal of phosphate from aqueous solution by biochar derived from anaerobically digested sugar beet tailings, J. Hazard. Mater., 190, 501-507, doi:10.1016/j.jhazmat.2011.03.083, 2011.

Ying, X., Xin-qing, L., Zhi-hong, Z., Hong-guang, C., Bin, F., and Like, Z.: Adsorption and Kinetics of Ammonium from Aqueous Medium onto Biochar, Earth Environ., 39, 511-516, 2011. 